\title{
Trauma e resistência na poesia de testemunho do Brasil contemporâneo
}

\section{Trauma and resistance in testimonial poetry of contemporary Brazil}

\author{
Wilberth SALGUEIRO \\ Universidade Federal do Espírito Santo / CNPq
}

\begin{abstract}
RESUMO: Se o trauma pode ser entendido como a rememoração incessante e difusa de algo não plenamente elaborado, a resistência então será uma atitude de corajoso enfrentamento dessa ferida não curada, daquilo que permanece em aberto. Neste sentido, os poemas que, desde sempre, tomam para si a tarefa de escrever e pensar as dores e catástrofes - que atingem o sujeito que fala por si e, sobretudo, por uma comunidade maior - podem ser lidos como uma espécie de cicatriz, que torna visíveis chagas e doenças de uma sociedade desigual e violenta. Há, no Brasil, uma expressiva produção poética que, no conjunto, poderia ser chamada de "poesia de testemunho". Embora minoritária (quando comparada ao excesso de poemas em torno da própria subjetividade e de virtuosismos de linguagem), essa poesia de testemunho cumpre um papel de resistência. A leitura de poemas de Alex Polari, Paulo Leminski, Jocenir e Miró da Muribeca se fará, basicamente, à luz da filosofia radical de Theodor Adorno.
\end{abstract}

PALAVRAS-CHAVE: Poesia de testemunho. Trauma. Resistência. Poesia brasileira.

ABSTRACT: If trauma can be understood as the incessant and fuzzy recollection of something not fully elaborated, then resistance will be an attitude of courageous confrontation of this unhealed wound, of what remains unclosed. In this sense, poems that take upon themselves the task of writing and thinking about the pain and disasters - that affect the subject who speaks for him or herself and, above all, in behalf of a larger community - can be read as some sort of scar, which unveils wounds and diseases of an unequal and violent society. There is, in Brazil, an expressive poetic production that, as whole, could be called "testimonial of poetry". Compared to the excessive number of poems about the own subjectivity and virtuosity of language, this testimonial of poetry is minimal. Yet it fulfills a resistance role. The reading of poems by Alex Polari, Paulo Leminski, Jocenir and Miró da Muribeca will be done, mainly, in light of the radical philosophy of Theodor Adorno.

KEYWORDS: Testimonial Poetry. Trauma. Resistance. Brazilian poetry

\section{Trauma, memória e resistência}

O verbete Trauma, no Vocabulário da Psicanálise, de Laplanche e Pontalis, sintetiza um modo possível de compreensão desse fenômeno: "Acontecimento da vida do sujeito que se define pela sua intensidade, pela incapacidade em que se encontra o sujeito de reagir a ele de forma adequada, pelo transtorno e pelos efeitos patogênicos duradouros que provoca na organização psíquica” (1998, p. 522). Assim, é na rememoração incessante do acontecimento intenso que o trauma sobrevive. O modo 
como cada um elabora o trauma vai determinar a continuidade e a intensidade de seus efeitos.

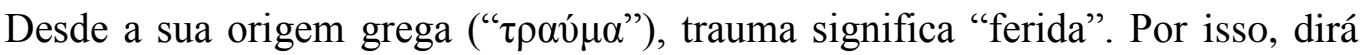
Jeanne Marie Gagnebin, "O trauma é a ferida aberta na alma, ou no corpo, por acontecimentos violentos, recalcados ou não, mas que não conseguem ser elaborados simbolicamente, em particular sob a forma de palavra, pelo sujeito" (2006, p. 110). Há uma dificuldade evidente em lidar com o fato traumático, pois isso implica tentar compreender suas causas mais profundas e seus efeitos muitas vezes devastadores. Algumas pessoas chegam mesmo a pôr termo à própria vida, diante da conclusão da impossibilidade de convívio com o trauma.

Para o enfrentamento de tão delicada condição, e não raro incompreendida pelo senso comum, sobretudo quando ganha a forma externa e corporal de um estado depressivo, Freud, em "Rememoração, repetição, perlaboração", afirma que o paciente deve "adquirir a coragem de fixar sua atenção sobre as manifestações de sua doença. Sua própria doença não pode mais ser para ele algo de vergonhoso, ela deve se tornar um adversário digno, uma parte de sua essência, cuja presença tem boas motivações e da qual poderá extrair elementos preciosos para sua vida posterior" (FREUD, in GAGNEBIN, 2006, p. 104). Nesta perspectiva, o trauma é uma doença que deve ser encarada de frente, apesar das dificuldades que tal postura implica. O trauma é normalmente associado a uma condição individual, mas há os chamados traumas coletivos, que incluem tragédias e catástrofes de grande porte.

Como se relacionam trauma e memória? Márcio Seligmann-Silva aponta um caminho: "o trauma é caracterizado por ser uma memória de um passado que não passa. O trauma mostra-se, portanto, como o fato psicanalítico prototípico no que concerne à sua estrutura temporal” (2000, p. 79). Sendo um passado que não passa, o trauma é, no entanto, atualizado a cada vez que, pela memória, vem à tona. Os traços nebulosos e lacunares do trauma ganham guarida no movimento da rememoração, também pleno de rasuras e incompletudes. O trauma rememorado se faz via linguagem, que tenta entender aquilo que, repetidamente, repele.

Nietzsche fala, em A genealogia da moral (1998), da estreita relação entre memória e esquecimento: este, quando em papel ativo, funciona como afirmador da vida e da renovação, celebrando o presente e evitando que a memória escravize o sujeito 
no passado, naquilo que já foi, caducou, pereceu: "Não conseguir levar a sério por muito tempo seus inimigos, suas desventuras, seus mal feitos inclusive - eis o indício de naturezas fortes e plenas, em que há um excesso de força plástica, modeladora, regeneradora, propiciadora do esquecimento" (1998, p. 31). Quando o esquecimento afirmativo, alegre, não se impõe, aparece a força reativa do ressentimento, que pode muitas vezes se assemelhar a um caráter doentio, vitimizante, compensatório do trauma.

Relato memorialístico impactante É isto um homem? (1998), de Primo Levi não hesita diante da validade de se registrar a memória do horror, dos campos de concentração, da barbárie humana: "Poderíamos, então, perguntar-nos se vale mesmo a pena, se convém que de tal situação humana reste alguma memória. A essa pergunta, tenho a convicção de poder responder que sim. Estamos convencidos de que nenhuma experiência humana é vazia de conteúdo, de que todas merecem ser analisadas; de que se podem extrair valores fundamentais (ainda que nem sempre positivos) desse mundo particular" (1988, p. 88). Levi lança mão, ainda que a duras penas, da memória para resgatar lembranças absolutamente traumáticas de sua experiência em Auschwitz, cumprindo o que muitos historiadores chamam de "dever de memória". Nas palavras de Paul Ricoeur, "O dever de memória é o dever de fazer justiça, pela lembrança, a um outro que não o si” (2007, p. 101). A recapitulação do trauma seria, assim, um doloroso exercício de memória com finalidade terapêutica, solidária, civilizatória.

De modo semelhante, Robert Antelme em seu relato A espécie humana explicita o desejo de falar: "trazíamos conosco nossa memória, nossa experiência ainda viva e experimentávamos um desejo frenético de contá-la exatamente como ela se passara. Entretanto, desde os primeiros dias, parecia impossível preencher a distância que descobríamos entre a linguagem de que dispúnhamos e essa experiência" (2013, p. 9). É no corpo que se inscreve o trauma e é do corpo que o trauma deve ser elaborado. Para alguns sobreviventes de genocídios e torturas, no entanto, o "dever de memória" se daria de outra forma, não sob a forma de relato (ou de qualquer outro registro documental ou artístico), que, sob certo olhar, soaria mesmo como uma ofensa - uma ofensa aos mortos.

No âmbito latino-americano e brasileiro, em função sobretudo dos períodos autoritários e ditatoriais, muitas vozes se fizeram ouvir, em registros memorialísticos os 
mais variados, trazendo informações, impressões e reflexões de traumas coletivos que atingiram nações inteiras.

Na Europa, na América, na África, ou onde quer que o trauma se produza, o papel da memória é capital, pois por ela o passado se presentifica. Mas se as causas que permitiram a eclosão do trauma persistem é que este passado ainda não foi elaborado, como dirá Adorno em “O que significa elaborar o passado” (1995 [1959]). É necessário, pois, cuidar, para que os elementos deste "indizível monstruoso" não retornem, embora estejam aí, perigosamente, a mancheias (nos indivíduos, nos hábitos, nas instituições). Maria Rita Kehl fala da necessidade imperiosa de, como alertou Freud, enfrentar o trauma: "Quando a sociedade não consegue elaborar os efeitos de um trauma e opta por tentar apagar a memória do evento traumático, esse simulacro de recalque coletivo tende a produzir repetições sinistras" $(2010$, p. 125). Por isso, é fundamental que se dê atenção e estímulo a iniciativas de resgate da memória, em particular de memórias soterradas pelo fantasma do trauma.

Como evitar que aqueles elementos monstruosos retornem? Com uma educação radical e maciçamente voltada para a autonomia e o esclarecimento, contra a coisificação do pensamento e a banalização da violência: "Se da experiência do trauma for removida a estranheza, o risco é a trivialização, a normalização daquilo que, pelo horror que constitui, não pode ser banalizado. O holocausto não pode se tornar normal, o massacre sistemático não pode ser trivial, os campos de concentração não podem se tornar eticamente aceitáveis", afirma, sem hesitar, Jaime Ginzburg (2012, p. 474). Este sujeito mais esclarecido tenderá a evitar essa banalização e essa espetacularização da dor. Possivelmente, em vez da morbidez do trauma, o sujeito quererá a vida, apesar da funda ferida, com sua doçura e beleza.

\section{Testemunho}

Testemunho é o relato, o depoimento, o documento, o registro (escrito, oral, pictórico, fílmico, em quadrinhos etc.). A testemunha, por excelência, é aquela que viveu a experiência, é um supérstite (superstes) - sobrevivente. Há outros graus de testemunha: há o testis, que se põe como terstis (terceiro) - que presenciou, que viu, que 
“testemunhou". E há, com o alargamento dos estudos de testemunho, a consideração da testemunha solidária, como dirá Jeanne Marie Gagnebin (2006, p. 57):

\begin{abstract}
testemunha não é somente aquele que viu com seus próprios olhos, o histor de Heródoto, a testemunha direta. Testemunha é aquele que não vai embora, que consegue ouvir a narração insuportável do outro e que aceita que suas palavras levem adiante, como num revezamento, a história do outro: não por culpabilidade ou por compaixão, mas porque somente a transmissão simbólica, assumida apesar e por causa do sofrimento indizível, somente essa retomada reflexiva do passado pode nos ajudar a não repeti-lo infinitamente, mas a ousar esboçar uma outra história, a inventar o presente.
\end{abstract}

O testemunho, por excelência, é feito/dado/produzido/elaborado pelo sobrevivente. Há, igualmente, os testemunhos de terceiros e de solidários. Cânones europeus do testemunho escrito são as obras de Primo Levi (narrativa: memória e contos) e Paul Celan (poesia), sobreviventes dos campos de concentração nazistas na Segunda Guerra. Na América Latina, destaca-se o nome e a luta da índia guatemalteca Rigoberta Menchú (depoimento oral dado à antropóloga Elizabeth Burgos), Nobel da Paz em 1992, e o "romance-testemunho" Biografía de un cimarrón (1966), do cubano Miguel Barnet.

No Brasil, sobressaem-se as obras que se relacionam aos períodos autoritários, em particular aos 21 anos da ditadura militar de 1964-85, e, mais ainda, aos 10 anos do período do AI-5 (13/12/1968 a 31/12/1978). Exemplos: O que é isso, companheiro?, de Fernando Gabeira; As meninas, de Lygia Fagundes Telles; Os carbonários, de Alfredo Sirkis. No cinema, recordem-se os filmes Que bom te ver viva! (1989), de Lúcia Murat, e Pra frente, Brasil! (1982), de Roberto Farias.

Numa ponta, bem ortodoxa, há a impossibilidade de existir testemunha (seja porque a morte é inenarrável, seja porque a linguagem falha); noutra ponta, bem maleável, a possibilidade plena de que, por um gesto simbólico de solidariedade, todos possam testemunhar. $\mathrm{O}$ que separa, então, o relato testemunhal e a literatura testemunhal? Separam-se?

Os estudos acerca do testemunho na literatura têm crescido consideravelmente. Esse crescimento se liga, sem dúvida, à onda (multi)culturalista. Em princípio, aliás, "literatura" seria o oposto de "testemunho" - e vice-versa. Este é um ponto nodal do debate. Por isso mesmo, as considerações acerca da "literatura de testemunho" envolvem questões de gênero, de valor, de saberes, que, mais uma vez, tensionam os 
limites entre estética e ética, entre verdade e ficção, entre realidade e representação. $O$ debate em torno do testemunho na literatura requer acercar-se não só de estudos literários (SELIGMANN-SILVA, 2005; GINZBURG, 2011), mas de boas doses de Filosofia (Gagnebin, 2006), Psicanálise (Caruth, 2000), Direito (Agamben, 2008), Sociologia (Bauman, 1998), História (Ricoeur, 2007) etc.

A noção fundadora de testemunho vem da chamada "literatura do Holocausto", emblematizada pelos relatos de sobreviventes da Segunda Guerra Mundial, como as citadas narrativas de Primo Levi e a poesia de Paul Celan. O alargamento desta noção inclui também sua utilização em direção ao passado, como, por exemplo, em relação aos genocídios e massacres contra índios e negros; ou em relação a misérias e opressões, desigualdades econômicas, preconceitos étnicos e sexuais do cotidiano em todo o mundo.

Alguns traços do testemunho:

De imediato, (1) o registro em primeira pessoa, como $O$ diário de Anne Frank, ou Os diários de Victor Klemperer, ou Sobrevivente André du Rap, do Massacre do Carandiru, em que o nome dos autores vem já estampado no título.

Também (2) um compromisso com a sinceridade do relato, que se verifica, por exemplo, em Diário de um detento, de Jocenir (e que não se verifica na fraude de Binjamin Wilkomirski, Fragmentos: memórias de infância-1939-1948).

Incontornável, no testemunho, é um (3) desejo de justiça, tal como observamos no romance Em câmara lenta, de Renato Tapajós, em particular na heroica e desesperada cena final, ou em Quarto de despejo, de Carolina Maria de Jesus, diário que registra as imensas dificuldades de uma negra e favelada na São Paulo dos anos 1950.

Intrínseco, ainda, ao discurso do testemunho é (4) a vontade de resistência, de não se conformar com as múltiplas faces do autoritarismo, como nos poemas de Leila Míccolis, ou em Meu nome é Rigoberta Menchú - e assim nasceu minha consciência, depoimento da índia dado à antropóloga Elizabeth Burgos.

Um traço fundamental do testemunho reside no (5) abalo da hegemonia do valor estético sobre o valor ético, conforme a poética, por exemplo, de Alex Polari, professada em Camarim de prisioneiro, ou as obras de Moacyr Félix e Thiago de Mello, 
ou A escrita ou a vida, de Jorge Semprun, em que tal questão sobrevém com intensidade.

Diferentemente da literatura tradicional, em que a subjetividade solitária se representa, importa no testemunho (6) a apresentação de um evento coletivo, como nos relatos de Primo Levi ou de Dráuzio Varella, feito É isto um homem? e Estação Carandiru, em que a primeira pessoa se faz porta-voz da dor de muitos.

A dor física e moral se fantasmagoriza, e a cicatriz fixa (7) a presença do trauma, como nos poemas cinzentos de Paul Celan ou mesmo no humor político de "A mancha", conto de Luis Fernando Verissimo, ou ainda em Memórias do esquecimento, de Flávio Tavares.

De forma compreensível, quando não se elabora o luto, o trauma pode se tornar (8) rancor e ressentimento, o que se constata nos relatos de Jean Améry, Elie Wiesel e, entre pitadas de humor negro e ironia, em Maus, narrativa em quadrinhos de Art Spiegelman.

Necessariamente, o (9) vínculo estreito com a história se faz fundamental, como em $O$ que é isso, companheiro?, de Fernando Gabeira, Poema sujo, de Ferreira Gullar, Grupo escolar, de Cacaso, ou Dulce pátria, do chileno Horacio Gutièrrez.

É constante um (10) sentimento de vergonha pelas humilhações e pela animalização sofridas, como atestam as memórias de Primo Levi, de Gustaw HerlingGrudziński ou de Graciliano Ramos.

Tal sentimento de vergonha tantas vezes se transforma num (11) sentimento de culpa por ter sobrevivido, enquanto a imensa maioria submergiu, como afirma, entre tantos, Robert Antelme em A espécie humana, ou Primo Levi, em vários textos.

Muitos sobreviventes preferiram se calar, por saberem que linguagem alguma seria capaz de re-apresentar o intenso sofrimento por que passaram. Esta (12) impossibilidade radical de re-apresentação do vivido/sofrido é tema contínuo dos testemunhos. Os depoimentos do livro Brasil: nunca mais (1986) dão uma mostra da dimensão dessa problemática.

A presença da ficção na confissão e no testemunho não invalida, em hipótese alguma, os traços gerais do "gênero testemunho" (híbrido, aliás, como os demais gêneros, subgêneros e outras formas podem ser). Ao contrário, este cruzamento 
amplifica a questão. Cada texto, cada caso há de propor protocolos e pactos, que hão de variar, certamente, a partir mesmo do repertório e do acolhimento do leitor.

No testemunho não há pretensão - diferentemente do que muitos pensam - de Verdade (absoluta), nem de Autoridade (total), mas não se aceita com tranquilidade a indistinção entre Verdade e Ficção/Mentira. No testemunho ortodoxo, isso tem implicações mesmo jurídicas. Falo naturalmente do testemunho clássico, paradigmático, como as narrativas de Primo Levi. Há muitos textos e obras e gêneros e graus distintos. No testemunho em geral, e na teoria do testemunho sempre, não há ingenuidade no sentido de uma crença no poder de representação "total" da linguagem. Ao contrário, a "indizibilidade" e a "irrepresentabilidade" são questões centrais do testemunho. Mas, sim, não se foge do real; tenta-se alcançá-lo. Aqueles que testemunham sabem já que o testemunho é “impossível”: falar/escrever é já "não-testemunhar”. O testemunho é uma urgência, um imperativo, uma utopia.

\section{Poesia e testemunho}

Nos estudos, cada vez mais numerosos, que se destinam a investigar as relações entre "testemunho e literatura no Brasil", é nítida, no entanto, a escassez de pesquisas que relacionam "testemunho e poesia". Para evidenciar a pouca visibilidade da poesia em estudos sobre testemunho, violência, autoritarismo e temas afins, tomemos uma pequeníssima amostragem:

(1) A Revista Literatura e autoritarismo n. $16^{1}$, com o dossiê "Rememoração e Reminiscência", referente a 2010/2, traz 10 artigos. Apenas 01 deles, intitulado "Poesia marginal: lírica e sociedade em tempos de autoritarismo", de Vitor Cei Santos, trata da produção poética, analisando a antologia 26 poetas hoje, de 1976.

(2) Já o dossiê "Escritas da violência IIl"2 (julho 2010) apresenta 18 artigos. Apenas 1 deles, bem curto, intitulado "Leitura do poema 'Janela do caos' [de Murilo Mendes] como manifestação escrita da violência", de Juan Rodriguez, tem um poema como texto central.

(3) $\mathrm{O} \mathrm{n}^{\mathrm{o}} 15$ dessa Revista ${ }^{3}$ trouxe o dossiê "Literatura brasileira: história e ideologia" (janeiro-junho 2010) com 9 artigos - nenhum sobre poesia.

\footnotetext{
${ }^{1}$ Disponível em: http://w3.ufsm.br/grpesqla/revista/num16/capa.php. Acesso em: 26 jul. 2015.

${ }^{2}$ Disponível em: http://w3.ufsm.br/grpesqla/revista/dossie03/sumario.php. Acesso em: 26 jul. 2015.

${ }^{3}$ Disponível em: http://w3.ufsm.br/grpesqla/revista/num15/sumario.php. Acesso em: 26 jul. 2015.
} 
(4) No dossiê "Cultura brasileira moderna e contemporânea"4 (dezembro 2009), há 12 artigos - mais uma vez, nenhum sobre poesia.

(5) No livro História, memória, literatura - o testemunho na era das catástrofes, organizado em 2003 por Márcio Seligmann-Silva, há 14 artigos, e apenas 1 (de Nancy Rosenchan) trata de poesia, a partir de dois poemas de Natan Alterman, poeta hebreu, elaborados tendo como base a história de Joãozinho e Maria de Grimm e a história bíblica de Abraão.

(6) Noutro importante volume, Catástrofe e representação, de 2000, com organização de Seligmann-Silva e Arthur Nestrovski, pode-se ler 10 artigos; nenhum sobre poesia.

(7) Esse quadro se confirma no livro Escritas da violência, vol 1: o testemunho, de 2012, em que apenas 1 dos 16 artigos ("A poesia em tempos de guerra: uma tentativa de ler a poesia brasileira contemporânea no contexto da violência", de Vera Lins) trata de poesia.

Nestas 07 publicações, portanto, temos um quadro que, com variações, se repetirá em outras hipotéticas amostragens: são 89 trabalhos ao todo, e apenas 04 tomam a poesia como foco e medula para o ensaio (ou seja, menos de 5\%). É preciso perguntarmo-nos, pois, por que a poesia anda escassa nos estudos de testemunho - em particular, no Brasil?

Nas três edições do simpósio "Literatura e testemunho", que coordenei com outros colegas, nos encontros da Abralic em 2011, 2013 e 2015, o quadro é bem similar: os trabalhos que tiveram como tema obras poéticas foram, sempre, amplamente minoritários. Em 2015, por exemplo, dos 21 trabalhos inscritos, 04 envolveram poesia, sendo 01 poeta polonês (Władysław Szlengel, comunicação do coordenador Marcelo Paiva, da UFPR), 1 trabalho teórico sobre poesia e testemunho (de Marcelo Ferraz, da UFG), 01 compositor brasileiro (Sérgio Sampaio, comunicação de Jorge Verly, doutorando sob minha orientação na Ufes) e 01 trabalho meu, intitulado " $O$ que testemunha a poesia brasileira contemporânea? Considerações a partir de obras indicadas ao Prêmio Portugal Telecom (2003-2014)". Em 2013, de 18 trabalhos, 03 falavam de poesia, sendo um meu e um de orientando meu. Na edição de 2011, foram 24 trabalhos tratando de poesia, sendo 2 de poesia polonesa e os outros 3 de minha autoria e de dois orientandos meus. No total das três edições, foram 63 trabalhos e 12 sobre poesia, com o "elevado" índice de 19\% de trabalhos envolvendo poesia, explicável pelo fato de os coordenadores pesquisarmos testemunho e poesia (brasileira e polonesa).

${ }^{4}$ Disponível em: http://w3.ufsm.br/grpesqla/revista/dossie02/sumario.php. Acesso em: 26 jul. 2015. 
Os motivos desta flagrante ausência de estudos articulando poesia (brasileira) e testemunho se explicam basicamente (mas não somente) por dois fatores: 1) a força da narrativa brasileira (autobiográfica ou não) de testemunho, que, sobretudo via alegoria, perscrutou as entranhas das máquinas de poder e extermínio de nosso governo ditatorial; 2) a peculiaridade do discurso lírico, que, altamente subjetivo, iria de encontro ao pressuposto básico do testemunho, ou seja, o grau de cumplicidade entre (a) aquele que fala - a testemunha e/ou sobrevivente; (b) aquilo de que se fala - a violência, a catástrofe, o eventolimite; e (c) a coletividade representada - vítimas e oprimidos.

Outros fatores poderiam explicar este sequestro do estudo da poesia sob a perspectiva testemunhal, como o próprio conceito de testemunho: se tomado de forma muito ortodoxa, os exemplos de "poesia de testemunho" escasseiam; ademais, em geral, sob qualquer perspectiva, os estudos sobre narrativas são hegemônicos.

Passemos agora a comentários do que entendemos por poesia de testemunho, escolhendo e analisando brevemente um poema de cada década a partir dos anos 1970:

\section{Poemas de testemunho}

\section{TORTURA - "Trilogia macabra", de Alex Polari, em Inventário de cicatrizes (1978)}

TRILOGIA MACABRA (I - O torturador)

O torturador

difere dos outros

por uma patologia singular

- ser imprevisível

vai da infantilidade total

à frieza absoluta.

Como vivem recebendo

elogios e medalhas

como vivem subindo de posto,

pouco se importam pelos outros.

Obter confissões é uma arte

o que vale são os altos propósitos

o fim se justifica,

mesmo pelos meios mais impróprios.

Além de tudo o torturador,

agente impessoal que cumpre ordens superiores no cumprimento de suas funções inferiores, não está impedido de ser um pai extremoso de ter certos rasgos

e em alguns momentos ser até generoso.

Além disso acredita que é macho, nacionalista, que a tortura e a violência são recursos necessários para a preservação de certos valores e se no fundo ele é um mercenário sabe disfarçar bem isso quando ladra.

Não se suja de sangue não macera nem marca (a não ser em casos excepcionais) o corpo de suas vítimas, trabalha em ambientes assépticos com distanciamento crítico - não é açougueiro é um técnico sendo fácil racionalizar que apenas põe a serviço da pátria da civilização e da família uma sofisticada tecnologia da dor que teria de qualquer maneira de ser utilizada contra alguém para o bem de todos. (p. 29) 
TRILOGIA MACABRA (II - O Analista de Informações)

Eles se acham muito humanos quando param de rodar a manivela começam a fazer só perguntas e agindo assim nos nivelam à categoria dos direitos humanos.

$\mathrm{O}$ analista é geralmente um senhor muito fino que vela pelo seu prestígio que fuma cigarros cem milímetros que se veste à paisana que usa belas gravatas coloridas parecendo mais um executivo bem sucedido do que um assassino.

Eles não torturam pessoalmente apenas dirigem os interrogatórios e têm muito orgulho disso - não são o céu nem o inferno, são o purgatório.

(p. 30)

\author{
TRILOGIA MACABRA \\ (III \\ Parafernália da Tortura) \\ Nos instrumentos de tortura ainda subsistem, é \\ verdade, \\ alguns resquícios medievais \\ como cavaletes, palmatórias, chicotes \\ que o moderno design \\ não conseguiu ainda amenizar \\ assim como a prepotência, chacotas \\ cacoetes e sorrisos \\ que também não mudaram muito. \\ Mas o restante é funcional \\ polido metálico \\ quase austero \\ algo moderno \\ com linhas arrojadas \\ digno de figurar \\ em um museu do futuro. \\ Portanto, \\ para o pesar dos velhos carrascos nostálgicos, \\ não é necessário mais rodas, trações, \\ fogo lento, azeite fervendo \\ e outras coisas \\ mais nojentas e chocantes. \\ Hoje faz-se sofrer a velha dor de sempre \\ hoje faz-se morrer a velha morte de sempre \\ com muito maior urbanidade, \\ sem precisar corar as pessoas bem educadas, \\ sem proporcionar crises histéricas \\ nas damas da alta sociedade \\ sem arrefecer os instintos \\ desta baixa saciedade. \\ (p. 31)
}

Desde a primeira estrofe se desenha a personalidade transtornada do torturador, marcada por uma instabilidade radical e por um temperamento psicótico. A ironia do poeta não impede o maquiavelismo do agente, que lança mão de qualquer meio para que a confissão se faça. O criminoso toma como pretexto o estar cumprindo ordens, reproduzindo o mote de Eichmann, como bem analisou Hannah Arendt (1999): torturo e mato a serviço do Estado (ou do rei, do führer, do patrão, do coronel etc.). A quarta estrofe explicita a diferença radical de valores: a agressividade, o nacionalismo estreito e a violência mercenária do torturador encontram resistência na delicadeza, na utopia e no desejo de esclarecimento do poeta prisioneiro. No último bloco, se denuncia o silêncio e a cumplicidade de parte da população, e mesmo a adesão e o apoio integrais de grupos direitistas e conservadores, como a TFP. Este silêncio social lembra, guardadas as extremas disparidades dos exemplos, "o biombo da ignorância deliberada" 
de que fala Primo Levi em Os afogados e os sobreviventes: "existe quem, diante da culpa alheia ou da própria, dá as costas a fim de não vê-la [a vergonha] nem se sentir por ela tocado: foi o que fez a maior parte dos alemães nos doze anos hitlerianos, na ilusão de que não ver significasse não saber e que não saber os livrasse de sua cota de cumplicidade ou de conivência. Mas a nós o biombo da ignorância deliberada foi negado: não pudemos deixar de ver. O mar de dor, passado e presente, nos circundava, e seu nível subia de ano em ano até quase nos fazer submergir. Era inútil fechar os olhos ou virar-lhe as costas, porque estava inteiramente em torno de nós, em toda direção até o horizonte" (1986, p. 74). Não basta um mea-culpa para dourar o biombo. É necessário muito mais, porque o fantasma de Auschwitz paira a todo momento por nossas cabeças, a cada genocídio mais ou menos visível e impactante, seja em guerras localizadas, seja nas cidades em que a mendicância e a miséria se multiplicam, incólumes, ignoradas pela máquina de produção de riquezas do Estado.

A segunda estrofe se inicia falando desse tema tão comum nos relatos de testemunho: os limites da condição humana - ultrapassados, o caminho é praticamente sem volta; animal, "muçulmano", o "não-homem" perde tudo: o corpo, a dignidade, a vontade, o pensamento, a linguagem; perde qualquer capacidade de resistir. $\mathrm{O}$ engenho da tortura é tomar conta do torturado, em todos os sentidos, de modo que nele se inscreva para sempre aquela crueldade, como se vê no conto "Na colônia penal" de Kafka. Entre nós, no Brasil setentista, vale recordar o relato de Gabeira, em que, com sincera autocrítica, se desveste de atitudes heróicas dos mártires: "Não tinha absolutamente forças para um comportamento do gênero turco -, nada tenho a declarar e vou morrer na tortura. Não era minha intenção morrer e temia que, partindo de um padrão tão alto, caísse muito baixo, quando começasse a abrir" (1996, p. 172). O analista de informações, funcionário teoricamente mais refinado que o torturador, lida com a psicologia do torturado, do preso, do ofendido, do subalterno. Em situação de extrema opressão e ofensa, as pessoas reagem de formas as mais variadas: resistem, gritam, choram, confessam, morrem, se suicidam. O interrogatório é um jogo - mas sem graça.

$\mathrm{Na}$ terceira parte da trilogia, o humor se produz com amargor, causando incômodo e constrangimento, pois se faz o "elogio" da eficiência asséptica da maquinaria de tortura contemporânea quando cotejada com os sujos e bárbaros instrumentos de tortura medievais. Em "Nas rodas do tempo", Ivete Keil descreve técnicas e modalidades de tortura física e moral que, ainda e sempre, espantam nossa razão: “A vítima, mergulhada 
numa banheira com água (mas também com vômitos, urina e excrementos), era forçada a engolir água por intermédio de uma mangueira, ou, ainda, recebia fortes jatos de água no rosto. Não mais se utilizava óleo quente e chumbo derretido sobre o corpo da vítima [como na Idade Média], mas torturava-se com eletricidade. (...) Essas formas de tortura não significaram a exclusão de pontapés, socos, golpes de palmatória e bastão, queimaduras de cigarro, xingamentos humilhantes, ameaças, paus de arara, geladeira, gavetão, cadeira do dragão, entre outras, igualmente crudelíssimas. Privações de alimentos e de água ou ingestão forçada de urina, fezes, vômitos, salmoura; extração de unhas e dentes sadios...” (p. 49). Diante de quadros horripilantemente dantescos como estes, é forçoso reconhecer que, aqui e ali, o humor seja presença non grata. No entanto, o artifício do humor no poema e na vida em geral não visa a apagar o feio, o vil, o bárbaro, o sórdido. Ao contrário, tal recurso pode nos fazer pensar com mais clareza o absurdo de certas coisas existirem a ponto de se naturalizarem em nosso cotidiano. Quando o poema diz que a parafernália da tortura era "algo moderno / com linhas arrojadas / digno de figurar / em um museu do futuro" está se valendo da ironia, aqui próxima do humor: ao afirmar que a referida parafernália teria lugar num "museu do futuro", a ambivalência (típica do humor e da ironia) se instala, pois este lugar não se daria necessariamente pelo seu valor de arte, mas possivelmente pelo seu valor de memória - uma memória que o poema alimenta.

\title{
5. HOLOCAUSTO - "lua à vista", de Paulo Leminski, em Distraídos venceremos (1987)
}

\author{
lua à vista \\ brilhavas assim \\ sobre auschwitz?
}

Seguindo a difícil lição que Seligmann aponta - "A esta altura da história e da reflexão estética não podemos considerar uma aporia intransponível a relação estabelecida entre as artes, o prazer e a denúncia e memória da dor e do mal" (2005, p. 97) -, tentemos detectar, com lente, ali na forma estética do poema o espírito ético que, possivelmente, fez com que ele se desse a ver exatamente desse jeito. Para tanto, não sendo muitas, comentemos brevemente cada uma das palavras e, em arremate, após, o conjunto do poema:

LUA: o abalo que Leminski realiza na imagem pura, mítica, quase unânime em torno do signo "lua", ganha ressonância na fala de Italo Calvino que, partindo de poemas de Leopardi, diz que, "Desde que surgiu nos versos dos poetas, a Lua teve sempre o poder de comunicar uma sensação de leveza, de suspensão, de silencioso e calmo encantamento" (1990, p. 37). Contra esse milenar encantamento que se encantoa bem longe dos problemas humanos, Leminski investe, diria até: triste, mas 
adornianamente sem amaciar. Sabe-se que o humor é uma das marcas da poética leminskiana. Aqui, nesse poema, no entanto, o gesto chistoso ou trocadilhesco fica em suspenso. A Lua, de eterna musa, vira ré, cúmplice, suspeita. E leva, junto, metonimicamente, a própria poesia. Aqui, Lua, "meu canto contigo não compactua".

À VISTA: embora em qualquer fase - nova, crescente, cheia, minguante - a Lua esteja "à vista", supomos que esta expressão reforce a ideia de "Lua cheia", dada a maior luminosidade que tal estado proporciona. Estar "à vista" pressupõe algum grau de exposição para os olhos alheios; localizar-se alta, inalcançável, aumenta o desejo, estimula o fetiche da posse afetiva. Não espanta - pela alta beleza da Lua que se exibe, ancestral, "à vista" - a absurda quantidade de obras que viram no astro um mote inspirador.

BRILHAVAS: o uso da segunda pessoa, "tu", confirma o tom sério e cerimonioso do poema, como se o verbo quisesse, pelo tratamento protocolar que incorpora, manter uma distância semelhante à que o satélite tem do nosso planeta. Esse tom - dado pelo "tu" - traz, se não exageramos na nota, um certo apelo brechtiano, antirromântico, ao eliminar do poema a primeira pessoa lírica, embora presuma-se que a pergunta seja feita por alguém, porta-voz de um grande grupo de pessoas inconformadas com a cumplicidade "sobre Auschwitz". Os sentidos sabidos de "brilhar" não escondem segredos: fulgurar, luzir, sobressair, seduzir pertencem ao campo afim das possibilidades semânticas.

ASSIM: "assim é um advérbio díctico [dêitico], isto é, está intimamente ligado ao momento e ao contexto situacional da enunciação, sem os quais o sentido da frase frequentemente fica incompleto" (HOUAISS, 2002). Associado aos elementos anteriores ("lua", "à vista" e "brilhavas"), o "assim", ou seja: "desse modo", parece-nos intensificar a grandeza e a beleza da Lua e de seu brilho, como se supuséssemos algo do tipo "brilhavas [tão bela] assim", ou "brilhavas [tão altaneira] assim", ou "brilhavas [tão soberba] assim"? Pelo teor de contraste que o poema apresenta (a beleza mitopoética da Lua vs o massacre histórico de Auschwitz), parece-nos improvável que o "assim" remeta a algo do tipo "brilhavas [tão triste] assim", ou "brilhavas [tão melancólica] assim".

SOBRE: assevera-nos o Houaiss que "sobre", de modo geral, "assinala situação de superioridade em relação a um limite concreto no espaço", como, por exemplo, a Lua em relação a Auschwitz. Estar "sobre", pois, ratifica literalmente o status do satélite e, de certo modo, embora incomparáveis, ratifica a hierarquia de um elemento (a Lua: universal, mítica, etérea e distante) sobre outro (Auschwitz: particular, histórico, concreto, entregue à própria sorte).

AUSCHWITZ: há, hoje, farto material sobre Auschwitz. Bastam-nos, por contundentes e complementares, duas breves análises: "do ponto de vista do historiador, o que está em questão com o Holocausto, com Auschwitz, não é a morte individual, que pode ser contada pela memória individual, mas o genocídio de um povo executado por um Estado moderno no coração da Europa em pleno século XX" (CYTRYNOWICZ, 2003, p. 133). As motivações pessoais que levaram Leminski (a) a inquirir a Lua, fazendo oscilar seu embolorado lugar de modelo poético, e (b) a selecionar o topos "Auschwitz", como exemplo de injustiça e desumanidade - isso não sabemos, mas especulamos. Na obra do curitibano, ocorrem várias aparições de "lua", em que ela exerce tranquilamente, sem pudores, o papel que vem da tradição e se perpetua tempos afora.

Leminski e Adorno concordariam com o agudo raciocínio de Gagnebin: "Criar em arte - como também em pensamento - 'após Auschwitz' significa não só rememorar 
os mortos e lutar contra o esquecimento, uma tarefa por certo imprescindível, mas comum à toda tradição desde a poesia épica, mas também acolher, no próprio movimento da rememoração, essa presença do sofrimento sem palavras, nem conceitos, que desarticula a vontade de coerência e de sentido de nossos empreendimentos artísticos e reflexivos" (2003, p. 106). Se entendermos, porém, que "sem palavras, nem conceitos" significa o silêncio - feito o da lua -, então não teríamos, literalmente, nem poemas nem ensaios. Só um eterno, e mudo, luto.

\section{SITUAÇÃO CARCERÁRIA - "Diário de um detento", de Jocenir, em Diário de um detento: o livro (1997)}

São Paulo, dia $1^{\circ}$ de outubro de 1992.

Oito horas da manhã.

Aqui estou, mais um dia.

Sob o olhar sanguinário do vigia.

Você não sabe como é caminhar

Com a cabeça na mira de uma HK.

Metralhadora alemã ou de Israel.

Estraçalha ladrão que nem papel.

Na muralha, em pé

Mais um cidadão-josé.

Servindo o Estado, um PM bom.

Passa fome metido a Charles Bronson.

Ele sabe o que eu desejo, sabe o que eu penso.

O dia tá chuvoso, o clima tá tenso.

Vários tentaram fugir, eu também quero.

Mas de um a cem a minha chance é zero.

(...) Ratatatá,

Mais um metrô vai passar.

Com gente de bem, apressada, católica,

Lendo jornal, satisfeita, hipócrita.

Com raiva por dentro a caminho do Centro,

Olhando pra cá curiosos - é lógico -,

Não, não é não, não é o zoológico.

(...) Já ouviu falar de Lúcifer?
Que veio do Inferno com moral um dia.

No Carandiru, não, ele é só mais um

Comendo rango azedo com pneumonia.

(...) Se um salafrário sacanear alguém,

Leva ponto na cara igual Frankstein

(...) Ratatatá,

Caviar e champanhe,

Fleury foi almoçar

Que se foda a minha mãe.

Cachorros assassinos, gás lacrimogêneo,

Quem mata mais ladrão ganha medalha de prêmio.

O ser humano é descartável no Brasil

Como modess usado ou bombril.

(...) Cadáveres no poço, no pátio interno,

Adolf Hitler sorri no Inferno.

O Robocop do Governo é frio,

Não sente pena, só ódio, e ri como a hiena.

(...) Mas quem vai acreditar no meu depoimento?

Dia 3 de outubro,

Diário de um detento.

Jocenir, na verdade Josenir Prado, foi preso, pelo que afirma, de forma injusta, envolvido numa confusão em que seu irmão era o protagonista. Fica anos de cadeia em cadeia, sem conseguir provar a inocência nem alcançar a liberdade. Passa por situações bastante desumanas, resiste, e aos poucos ganha alguma autoridade entre os pares de prisão, dada a sua intimidade com as letras. Por isso, é levado a conhecer o rapper Mano Brown, dos Racionais MCs, que musica versos seus que ganham notoriedade, tornando-se canção e videoclipe de grande sucesso - "Diário de um detento". Tal poema, longo, vem estampado ao fim de seu relato testemunhal Diário de um detento o livro, que, alavancado pela música, teve grande repercussão, tornando-se uma das 
narrativas mais conhecidas entre as tantas que vêm surgindo sob o rótulo "literatura carcerária".

O poema fala do Massacre do Carandiru, ocorrido em 2 de outubro de 1992. Notese que se inicia no dia $1^{\circ}$, e se encerra no dia 3 de outubro. Chama a atenção o conjunto de referências e analogias que o poema aciona: "HK. Metralhadora alemã ou de Israel”, Charles Bronson, Lúcifer, Frankestein, Fleury, modess e Bombril, Hitler etc. Há muitas rimas surpreendentes: HK / caminhar, PM bom / Charles Bronson, alguém / Frankstein, champanhe / mãe. O preso se sente um animal no zoológico, ser exótico à vista alheia, de "gente de bem, apressada, católica, / Lendo jornal, satisfeita, hipócrita". Mesmo o poder de Lúcifer se curva ao real "azedo" da prisão. Passa-se do mito (Lúcifer) à história, na figura do delegado Fleury, acusado como responsável maior pela chacina do Carandiru, chacina que lembra ao preso-poeta a situação demasiadamente desumana dos prisioneiros nos campos de concentração, conforme sinaliza, de modo cru, o riso zombeteiro de Hitler no inferno.

O tom cáustico, cru, que traz o grotesco à tona, lembra máxima de Freud ("O humor não é resignado, mas rebelde"; "Der Humor ist nicht resigniert, er ist trotzig"), comentada por Daniel Kupermann e que aqui vem a propósito: “É nessa rebeldia (ou teimosia, uma vez que a palavra alemã trotzig aceita também como tradução possível teimoso) que consiste a dimensão ética do humor, cujo sentido estacado por Freud é 'não apenas o triunfo do ego, mas também o do princípio do prazer, que pode aqui afirmar-se contra a crueldade das circunstâncias reais"” (KUPERMANN, 2003, p. 56). A arte, mesmo quando vinda de trevas, pode se elaborar tendo - em sentido lato, sempre - o humor como técnica de construção.

\section{MISÉRIA DAS PERIFERIAS - "Carla", de Miró da Muribeca, em Poemas pra sentir tesão (ou não) (2004)}

Conheci Carla catando lata

Seus olhos brilhavam

Como alumínio ao sol

São Paulo ardia

Num calor de quase quarenta graus

Pisou na lata

Como pisam os policiais

Nos internos da Febem

Jogou no saco

Com a precisão que os

Internos jogam

Monitores dos telhados
E rápido foi embora,

Tal qual sequestro relâmpago

Deixando a lembrança

De um tempo que

Não havia sequestros,

Febem,

Nem tanta polícia,

Muito menos catadores de lata,

Os olhos de Carla

Nem desse poema precisavam. 
Xavier Crettiez, em As formas da violência (2008), trata de aspectos diversos da violência, desde os modos como alguém adere a ela, a violência do Estado, a violência terrorista, as mudanças nas "formas da violência" e o papel contemporâneo fundamental da ação e da influência da mídia. $\mathrm{O}$ autor resume o que compreende como as três grandes formas de violência: "[a] uma violência de cálculo, praticada por atores institucionais ou organizados como o Estado, os movimentos sociais os grupos políticos; [b] uma violência passional, motivada por raiva, frustração e medo; [c] uma violência identitária que pode ser tanto a do Estado como a de outros atores sociais, preocupados em demonstrar, pela violência, uma posição, a existência de uma comunidade, ou em fornecer um discurso de distinção em relação ao outro violentado" (p. 138).

Octavio Ianni, em Capitalismo, violência e terrorismo (2004), diz que a cidade é o palco em que se dá a competição desenfreada, sem estímulos para harmonia e solidariedade. Em um quadro bastante heteróclito, a violência explode em múltiplas manifestações, exigindo múltiplas formas de interpretação: "em geral, a fúria da violência tem algo a ver com a destruição do 'outro', 'diferente', 'estranho”' (p. 168), e assim as assimetrias se tornam incontornáveis e intoleráveis: ricos, remediados e pobres; negros, brancos, mulatos; credos e crenças distintas, times de futebol, condutas no trânsito, opiniões políticas, sexualidades, tudo se torna um pavio prestes a se acender.

Em "Carla", de Miró da Muribeca (Recife), aparece boa parte dos traços da violência discutidos pelos estudiosos. O poema de Miró, com seus 22 versos, fala de uma catadora de lata e, a partir dela, desenha um quadro cruel de nossa sociedade, em que se misturam desemprego, exploração, abuso de poder, sequestro, violência urbana; o poema, ao fim, questiona a própria necessidade de existir, diante de realidades tão impactantes. A existência mesma do poema parece responder ao questionamento, reforçando a ideia de arte como resistência à catástrofe, conforme reflexões de Adorno em Teoria estética: "Pela recusa intransigente da aparência de reconciliação, a arte mantém a utopia no seio do irreconciliado, consciência autêntica de uma época, em que a possibilidade real da utopia - o facto de a terra, segundo o estado das forças produtivas, poder ser aqui e agora o paraíso - se conjuga num ponto extremo com a possibilidade da catástrofe total" (2008, p. 58). 
A catástrofe do cotidiano toma forma no poema e, para pensar isso, é produtivo investigar o conceito de conteúdo de verdade, que diz respeito ao modo como a história se inscreve na arte. A arte (logo, um poema ou um livro de poemas) é sempre um enigma formal, que dependerá de uma visada crítica (de "reflexão filosófica", dirá Adorno) para seu possível vislumbre. O conteúdo de verdade, a despeito de qualquer intenção autoral, está na obra, no objeto, no poema, é dali que deve ser desentranhado: "O conteúdo de verdade das obras de arte é a resolução objectiva do enigma de cada uma delas. Ao exigir a solução, o enigma remete para o conteúdo de verdade, que só pode obter-se através da reflexão filosófica"; "o conteúdo de verdade não existe fora da história, mas constitui a sua cristalização nas obras" (ADORNO, 2008, p. 149 e 154). Para o filósofo alemão, a potência máxima que se pode experimentar de uma obra de arte é o entendimento de seu caráter histórico, isto é, como uma obra - feito a de Beckett, Kafka ou Schoenberg - capta o tempo de que participa e elabora esse tempo em forma objetiva, mesmo que nos moldes de uma "historiografia inconsciente".

O poema "Carla", de Miró da Muribeca, se presta, em particular, para uma reflexão que tenta apreender, por exemplo, como a história brasileira contemporânea se mostra através da mediação da escrita de um sujeito que está, também, extremamente atento às coisas, às pessoas e aos fatos de seu entorno. Se o entorno é recheado de violência e opressão, o poema há de incorporar em sua trama sinais desse triste e melancólico recheio.

\section{Considerações finais}

Se o trauma pode ser entendido como a rememoração incessante e difusa de algo não plenamente elaborado, a resistência então será uma atitude de corajoso enfrentamento dessa ferida não curada, daquilo que permanece em aberto.

Neste sentido, os poemas que, desde sempre, tomam para si a tarefa de escrever e pensar as dores e catástrofes - que atingem o sujeito que fala por si e, sobretudo, por uma comunidade maior - podem ser lidos como uma espécie de cicatriz, que torna visíveis chagas e doenças de uma sociedade desigual e violenta.

Há, no Brasil, uma expressiva produção poética que, no conjunto, poderia ser chamada de "poesia de testemunho".

Embora minoritária (quando comparada ao excesso de poemas em torno da própria subjetividade e de virtuosismos de linguagem), essa poesia de testemunho 
cumpre um papel de resistência, quando traz, desde décadas e até hoje, ao centro do palco temas como a tortura (Alex Polari, "Trilogia macabra", 1978); o holocausto (Paulo Leminski, "lua à vista", 1987); a situação carcerária (Jocenir, "Diário de um detento", 1997) e a miséria das periferias (Miró da Muribeca, "Carla”, 2004).

A leitura desses poemas confirma a filosofia radical de Theodor Adorno, em Teoria estética: "valia mais desejar que um dia melhor a arte desapareça do que ela esquecer o sofrimento, que é a sua expressão e na qual a forma tem a sua substância".

No mundo real, sem utopia, poemas como esses - que incorporam o sofrimento de que tratam - não deixam a arte desaparecer.

\section{Referências}

ADORNO, Theodor. O que significa elaborar o passado [1959]. Educação e emancipação. Tradução: Wolfgang Leo Maar. Rio de Janeiro: Paz e Terra, 1995, p. 29-49.

ADORNO, Theodor. Teoria estética. Tradução: Artur Morão. Lisboa: Edições 70, 2008.

AGAMBEN, Giorgio. O que resta de Auschwitz: o arquivo e a testemunha (Homo Sacer III). Tradução: Selvino J. Assmann. São Paulo: Boitempo, 2008.

ANDRÉ DU RAP. Sobrevivente André du Rap, do Massacre do Carandiru. Coordenação editorial: Bruno Zeni. São Paulo: Labortexto, 2002.

ANTELME, Robert. A espécie humana. Tradução: Maria de Fátima Oliva do Coutto. Rio de Janeiro: Record, 2013.

ARENDT, Hannah. Eichmann em Jerusalém, um relato sobre a banalidade do mal. Tradução: José Rubens Siqueira. São Paulo: Companhia das Letras, 1999.

ARNS, Dom Paulo Evaristo (org.). Brasil: nunca mais. 19. ed. Petrópolis, RJ; Vozes, 1986.

BAUMAN, Zygmunt. Modernidade e holocausto. Tradução: Marcus Penchel. Rio de Janeiro: Jorge Zahar Ed., 1998.

BURGOS, Elizabeth. Meu nome é Rigoberta Menchú - e assim nasceu minha consciência. Tradução: Lólio Lourenço de Oliveira. Rio de Janeiro: Paz e Terra, 1993.

CALVINO, Italo. Seis propostas para o próximo milênio. Tradução: Ivo Barroso. São Paulo: Companhia das Letras, 1990.

CARUTH, Cathy. Modalidades do despertar traumático (Freud, Lacan e a ética da memória). NESTROVSKI, Arthur, SELIGMANN-SILVA, Márcio (orgs.). Catástrofe e representação: ensaios. São Paulo: Escuta, 2000, p. 111-136.

CRETTIEZ, Xavier. As formas da violência. Tradução: Lara Christina Malimpensa e Mariana Cunha. São Paulo: Loyola, 2011.

CYTRYNOWICZ, Roney. O silêncio do sobrevivente: diálogo e rupturas entre memória e história do Holocausto. SELIGMANN-SILVA, Márcio (org.). História, memória, literatura: o testemunho na era das catástrofes. Campinas, SP: Editora da Unicamp, 2003, p. 125-140.

FREUD, Sigmund. Rememoração, repetição, perlaboração. GAGNEBIN, Jeanne Marie. O que significa elaborar o passado? Lembrar escrever esquecer. São Paulo: Ed. 34, 2006, p. 97-105.

GABEIRA, Fernando. O que é isso, companheiro? São Paulo: Companhia das Letras, 1996.

GAGNEBIN, Jeanne Marie. "Após Auschwitz". SELIGMANN-SILVA, Márcio (org.). História, memória, literatura: o testemunho na era das catástrofes. Campinas, SP: Editora da Unicamp, 2003, p. $91-112$. 
GAGNEBIN, Jeanne Marie. O rastro e a cicatriz: metáforas da memória. Lembrar escrever esquecer. São Paulo: Ed. 34, 2006, p. 107-118.

GINZBURG, Jaime. Escritas da tortura. Crítica em tempos de violência. São Paulo: Edusp, Fapesp, 2012, p. 473-491.

GINZBURG, Jaime. Linguagem e trauma na escrita do testemunho. SALGUEIRO, Wilberth (org.). O testemunho na literatura: representações de genocídios, ditaduras e outras violências. Vitória: Edufes, 2011, p. 19-29.

GUTIÈRREZ, Horacio. Dulce patria. Santiago: RIL Editores, 2012.

HOUAISS, Antônio. Dicionário eletrônico Houaiss da língua portuguesa. Rio de Janeiro: Editora Objetiva, 2002.

IANNI, Octavio. Capitalismo, violência e terrorismo. Rio de Janeiro: Civilização brasileira, 2004.

JOCENIR. Diário de um detento: o livro. São Paulo: Labortexto, 2001.

KEHL, Maria Rita. Tortura e sintoma social. TELES, Edson; SAFATLE, Vladimir (orgs.). O que resta da ditadura. São Paulo: Boitempo, 2010, p. 123-132.

KEIL, Ivete. Nas rodas do tempo. O corpo torturado. Ivete Keil, Márcia Tiburi (orgs.). Porto Alegre: Escritos Editora, 2004, p. 41-60.

KUPPERMANN, Daniel. Ousar rir: humor, criação e psicanálise. Rio de Janeiro: Civilização Brasileira, 2003.

LAPLANCHE, Jean; PONTALIS, Jean-Bertrand. Vocabulário da Psicanálise. 3. ed. São Paulo: Martins Fontes, 1998.

LEMINSKI, Paulo. Distraídos venceremos. São Paulo: Brasiliense, 1987.

LEVI, Primo. É isto um homem? Tradução: Luigi Del Re. Rio de Janeiro: Rocco, 1988.

LEVI, Primo. Os afogados e os sobreviventes: os delitos, os castigos, as penas, as impunidades. Tradução: Luiz Sérgio Henriques. Rio de Janeiro: Paz e Terra, 1990.

MíCCOLIS, Leila. Em perfeito mau estado [1987]. Desfamiliares: poesia completa de Leila Míccolis (1965-2012). São Paulo: Annablume, 2013.

MIRÓ (Pseudo). SILVA, João Flávio Cordeiro. Poemas pra sentir tesão (ou não). Disponível em: http://naredecommiro.blogspot.com.br/. Acesso em 26 fev. 2014.

NIETZSCHE, Friedrich. Genealogia da moral. Tradução, notas e posfácio: Paulo César de Souza. São Paulo: Cia. das Letras, 1998.

POLARI, Alex. Inventário de cicatrizes [1978]. 4. ed. Rio de Janeiro: Global, 1979. [Publicado pela Global para Comitê Brasileiro pela Anistia / RJ e Teatro Ruth Escobar.]

SALGUEIRO, Wilberth (org.). O testemunho na literatura: representações de genocídios, ditaduras e outras violências. Vitória: Edufes, 2011.

SELIGMANN-SILVA, Márcio (org.). História, memória, literatura: o testemunho na era das catástrofes. Campinas, SP: Ed. Unicamp, 2003.

SELIGMANN-SILVA, Márcio. A história como trauma. NESTROVSKI, Arthur; SELIGMANN-SILVA, Márcio (orgs.). Catástrofe e representação. São Paulo: Escuta, 2000, p. 73-98.

SELIGMANN-SILVA, Márcio. Literatura de testemunho: os limites entre a construção e a ficção. O local da diferença: ensaios sobre memória, arte, literatura e tradução. São Paulo: Ed. 34, 2005, p. 105-118.

SELIGMANN-SILVA, Márcio. Literatura e trauma: um novo paradigma. O local da diferença: ensaios sobre memória, arte, literatura e tradução. São Paulo: Ed. 34, 2005, p. 63-80.

VERISSIMO, Luis Fernando. A mancha. São Paulo: Companhia das Letras, 2004. (Coleção Vozes do golpe)

WILKOMIRSKI, Binjamin. Fragmentos: memórias de infância - 1939-1948. Tradução: Sérgio Tellaroli. São Paulo: Companhia das Letras, 1998. 